\title{
MLL/GMPS Fusion Protein
}

National Cancer Institute

\section{Source}

National Cancer Institute. MLL/GMPS Fusion Protein. NCI Thesaurus. Code C99326.

A fusion protein encoded by the MLL/GMPS fusion gene. This protein is comprised of the $\mathrm{N}$-terminal half of the histone-lysine $\mathrm{N}$-methyltransferase MLL protein, including the AT hook DNA binding domain and the DNA methyltransferase domain, fused to almost the entire GMP synthase [glutamine-hydrolyzing] protein. 